\title{
GAGASAN PENDIDIKAN MUHAMMADIYAH DAN NU SEBAGAI POTRET PENDIDIKAN ISLAM MODERAT DI INDONESIA
}

\author{
Toto Suharto \\ Institut Agama Islam Negeri Surakarta, Indonesia \\ E-mail: tosuh71@gmail.com
}

\begin{abstract}
This article deals with the educational ideas of Muhammadiyah and Nahdatul Ulama as representing the portrait of moderate Islamic education in Indonesia. The problems addressed includes whether both organizations have certain moderate ideas regarding education to seed their moderate character. Using actual philosophy approach, this study reveals that educational institutions of Muhammadiyah are characterized by a special subject matter called Al-Islam dan Kemuhammadiyahan. With the concept of objective identity of Muhammadiyah's education, this subject matter is designed to be an instrument for Muhammadiyah to seed the moderate character of its students. Meanwhile, NU's educational institutions are characterized by subject matter called Aswaja dan Ke-NU-an. Through the concept of SNPPlus, this institution serves as an instrument for NU to seed the character of moderate Islam. Both organizations therefore share the same ideas to strengthen a moderate Islamic education in Indonesia on the basis of their own cultural traditions.
\end{abstract}

Keywords: Muhammadiyah, Nahdatul Ulama, Al-Islam dan Kemuhammadiyahan, Aswaja dan Ke-NU-an.

\section{Pendahuluan}

Islam di Indonesia telah memerkuat dirinya dalam proses sejarah yang sangat panjang. ${ }^{1}$ Secara keseluruhan, proses historis ini dilakukan dengan damai, yang berbeda dengan Islamisasi di kawasan lain di

\footnotetext{
1 Paling tidak ada empat teori yang berbicara tentang proses masuknya Islam ke Indonesia, yaitu teori Arab, teori India, teori Iran, dan teori Cina. Perdebatan menarik tentang keempat teori ini. Lihat Nor Huda, Islam Nusantara: Sejarah Sosial Intelektual Islam di Indonesia (Yogyakarta: Ar-Ruzz Media, 2007), 31-43.
} 
belahan dunia Islam. Islamisasi dengan damai ini dilukiskan Thomas W. Arnold sebagai berikut:

"Sketsa di atas hanyalah merupakan bagian kecil daripada sejarah dakwah Islam di kepulauan Nusantara...Tetapi cukup bukti-bukti yang menunjukkan adanya pelaksanaan dakwah Islam yang berjalan dengan penuh damai selama 600 tahun terakhir...ajakan dan bujukanlah yang mewarnai gerakan dakwah itu". ${ }^{2}$

Proses Islamisasi dengan damai itu segera berubah ketika Indonesia memasuki era reformasi 1998. Menurut catatan Tim PUSHAM UII, akhir masa Orde Baru merupakan momentum penting bagi kebangkitan Islam di Indonesia, yang menjadi prakondisi bagi munculnya berbagai kelompok gerakan Islam "baru", termasuk gerakan Islam radikal. Dalam atmosfer kebebasan inilah bermunculan aktor gerakan Islam baru, yang berada di luar kerangka mainstream Islam Indonesia yang dominan, semisal NU, Muhammadiyah, Persis, al-Irsyad, al-Wasliyah, Jamiat Khair dan sebagainya. Organisasi-organisasi semisal Gerakan Tarbiyah (yang kemudian menjadi Partai Keadilan Sejahtera), Hizbut Tahrir Indonesia (HTI), Majelis Mujahidin Indonesia (MMI), Front Pembela Islam (FPI), Laskar Jihad dan sebagainya merupakan representasi generasi baru gerakan Islam di Indonesia itu. ${ }^{3}$

Oleh Ahmad Syafi'i Mufid beberapa gerakan yang berada di luar mainstream Islam Indonesia itu disebut sebagai gerakan transnasional, yaitu kelompok keagamaan yang memiliki jaringan internasional, yang datang ke suatu negara dengan membawa paham keagamaan (ideologi) baru dari negeri seberang (Timur Tengah), yang dinilai berbeda dari paham keagamaan lokal yang lebih dahulu eksis. Beberapa kelompok keagamaan Islam atau gerakan yang dianggap transnasional adalah al-Ikhwân al-Muslimûn (Gerakan Tarbiyah) dari Mesir, Hizbut Tahrir Indonesia (HTI) dari Libanon (Timur Tengah),

\footnotetext{
2 Thomas W. Arnold, Sejarah Dakwah Islam, terj. A. Nawawi Rambe Jakarta: Widjaya, 1985), 352. Pandangan yang paling luas diterima menyatakan bahwa Islam berhasil diterima secara damai oleh masyarakat Indonesia lewat ajaran-ajaran para sufi. Jika dibandingkan dengan cabang-cabang disiplin Islam yang lain, tasawuf pada umumnya diakui sebagai disiplin yang paling besar perannya dalam penyebaran Islam di Indonesia. Lihat Alwi Shihab, "The Muhammadiyah Movement and Its Controversy with Christian Mission in Indonesia" (Disertasi--Temple University, 1995), 18-19.

3 Tim PUSHAM UII, Bersama Bergerak: Riset Aktivis Islam di Dua Kota (PUSHAM UII: Yogyakarta, Oktober 2009), 38.
} 
Salafi dari Saudi Arabia, Shî‘ah dari Iran dan Jamaah Tabligh dari India/Bangladesh. Keenam gerakan atau kelompok keagamaan Islam tersebut, saat ini sudah ada di Indonesia, berupaya menancapkan pahamnya melalui lembaga pesantren, perguruan tinggi atau kampuskampus, majelis-majelis ta lìm, lembaga-lembaga amil zakat, infak, dan sedekah. Karena mereka membawa paham keagamaan (ideologi) baru, maka dalam perkembangannya, acap kali mereka menimbulkan gesekan dengan beberapa kelompok keagamaan Islam yang telah lebih dahulu ada. ${ }^{4}$ Disadari atau tidak, para aktivis gerakan tersebut berhasil menakhodai aktivitas beberapa masjid, terutama di wilayah perkotaan. Akan tetapi, di beberapa tempat muncul kasus berupa letupan reaksi masyarakat terhadap eksistensi mereka, disebabkan cara pandang yang berbeda dalam memahami dakwah. ${ }^{5}$

Sejak itu, berbagai peristiwa yang disebut radikalisme dan terorisme sering menghantui Indonesia, mulai Bom Bali dan bombom lainnya di berbagai wilayah Indonesia. Untuk meresponsi hal ini, untuk kali pertama diadakanlah konferensi ulama se-ASEAN, yaitu The Jakarta International Islamic Conference, dengan tema "Strategi Dakwah Menuju Ummatan Wasathon dalam Menghadapi Radikalisme", untuk menyiasati maraknya radikalisme di Indonesia. Konferensi ini diselenggarakan atas prakarsa Majelis Tabligh dan Dakwah Muhammadiyah bekerjasama dengan Lembaga Dakwah NU, pada tanggal 13-15 Oktober 2003 di Gedung JCC Jakarta. ${ }^{6}$ Menurut Hery Sucipto, konferensi inilah yang mengilhami kehadiran Center for Moderate Moslem (CMM) yang dikomandoi Muhammadiyah dan NU, untuk mengusung "Islam Jalan Tengah" bagi Islam Indonesia, di tengah kerasnya tarik-menarik antara kelompok atau gerakan Islam radikal dengan Jaringan Islam Liberal (JIL). ${ }^{7}$

Kemunculan CMM oleh Muhammadiyah dan NU dengan mengusung Islam moderat kiranya perlu mendapat dukungan dari

\footnotetext{
${ }^{4}$ Ahmad Syafi'i Mufid (ed.), Perkembangan Paham Keagamaan Transnasional di Indonesia (Jakarta: Puslitbang Kehidupan Keagamaan, Badan Litbang dan Diklat Kementerian Agama, 2011), 215-216.

${ }^{5}$ Ibid., ix.

${ }^{6}$ Lihat Nurul Badruttaman, "Dakwah Islam di Tengah Tantangan Globalisasi: Pemikiran dan Kontribusi Tarmizi Taher" dalam Hery Sucipto (ed.), Islam Madžbab Tengah: Persembahan 70 Tahun Tarmizi Taher (Jakarta: Grafindo Khazanah Ilmu, 2007), 329.

7 Hery Sucipto, “Tarmizi Taher dan Islam Madzhab Tengah”, pengantar editor dalam Hery Sucipto (ed.), Islam Madzhab Tengab: Persembaban 70 Tabun Tarmizi Taher (Jakarta: Grafindo Khazanah Ilmu, 2007), 17.
} 
seluruh elemen masyarakat Islam Indonesia, sebab bagaimanapun juga, Indonesia adalah "negerinya kaum Muslim moderat", demikian penilaian Abdurrahman Wahid. Sejak masa pasca-Soeharto, Indonesia sebagai negara Muslim terbesar dan negara demokrasi ketiga setelah India dan Amerika Serikat, diharapkan dapat memainkan peran lebih besar di dalam menyebarkan Islam wasatiyah, yang oleh sebagian kalangan diidentikkan dengan Islam moderat. Dalam konteks ini, Kementerian Agama sebagai lembaga formal milik pemerintah telah berupaya untuk menanamkan Islam moderat bagi Islam Indonesia. Menteri Agama, yang saat itu dipegang oleh Suryadharma Ali pernah menyatakan bahwa "Islam Indonesia adalah Islam moderat yang mengutamakan toleransi dan kebhinekaan". Kemudian Wakil Presiden Jusuf Kalla pada saat membuka Konferensi ke-VI Umat Islam Indonesia, di Pagelaran Keraton Yogyakarta, pada 9 Februari 2015 mengatakan: "Indonesia harus menjadi referensi pemikiran Islam dunia yang moderat. Islam yang jalan tengah". ${ }^{10}$

Secara khusus, Azyumardi Azra memandang Islam Indonesia sebagai "Islam with a smiling face" yang penuh damai dan moderat, sehingga tidak ada masalah dengan modernitas, demokrasi, HAM dan kecenderungan-kecenderungan lain di dunia modern. ${ }^{11}$ Akan tetapi, apakah karakter moderat bagi Islam Indonesia itu dapat dipertahankan dewasa ini? Ini semua tergantung kepada pemeluk agama ini. Di sinilah perlunya penyemaian dan penguatan Islam moderat melalui jalur pendidikan, baik secara formal, informal dan nonformal, baik oleh pemerintah maupun lembaga swadaya masyarakat. Muhammadiyah dan NU yang sejak awal dicap sebagai pengusung Islam moderat, diharapkan memiliki andil besar bagi pemberdayaan Islam moderat bagi Indonesia. ${ }^{12}$ Menurut Muhammad

${ }^{8}$ Penilaian ini diberikan Abdurrahman Wahid, ketika melihat perkembangan Islam Indonesia. Lihat Abdurrahman Wahid, Islamku, Islam Anda, Islam Kita: Agama Masyarakat Negara Demokrasi (Jakarta: The Wahid Institute, 2006), 60.

9 Koran Sindo versi online, "Kemenag Dorong UIN Jadi Kampus Riset" dalam http://m.koran-sindo.com/node/325385, (diakses pada 1 Juni 2014).

10 "Indonesia Diharapkan Jadi Barometer Islam Moderat" dalam http://www.nu.or.id/ (diakses pada 29 Maret 2015).

11 Azyumardi Azra, "Bali and Southeast Asian Islam: Debunking the Myths" dalam Kumar Ramakrishna dan See Seng Tan (eds.), After Bali: The Threat of Terrorism in Southeast Asia (Singapore: World Scientific Publishing Co. Pte. Ltd, 2003), 45.

12 Lihat Azyumardi Azra, "Distinguishing Indonesian Islam: Some Lessons to Learn" dalam Jajat Burhanudin dan Kees van Dijk (eds.), Islam in Indonesia: 
Ali, sudah saatnya ormas-ormas agama seperti NU dan Muhammadiyah yang bergaris moderat, untuk membimbing kelompok-kelompok agama agar lebih mengedepankan kearifan (wisdom), bukan teror dan kekerasan, dalam menyalurkan militansi keagamaan mereka. ${ }^{13}$ Hal ini karena keberagamaan yang mampu menolak terorisme selalu berawal dari sikap keberagamaan yang moderat, yang berupaya mengembangkan penafsiran teks-teks keagamaan dengan bahasa agama yang damai, santun, dan bijaksana, sehingga orientasi keberagamaannya tidak berhenti pada to have a religion, tetapi lebih penting dari itu adalah to be religious. ${ }^{14}$

Tulisan ini dengan analisis filsafat aktual ${ }^{15}$ bermaksud mengkaji ulang sejauh mana lembaga pendidikan yang dikelola Muhammadiyah dan NU itu mengusung gagasan pendidikan Islam moderat. Kajian ulang terhadap gagasan pendidikan Islam moderat kedua organisasi ini penting dilakukan, agar dapat dipastikan bahwa outcome dari lembaga pendidikan kedua organisasi ini memiliki peran penting bagi penyemaian dan penguatan Islam moderat di Indonesia, sehingga tesis Jajat Burhanudin dan Kees van Dijk yang berpandangan bahwa dengan karakter modeat, Islam Indonesia dapat dijadikan model bagi keberagamaan Islam di seluruh dunia Muslim, ${ }^{16}$ dapat diuji keberadaannya.

\section{Kerangka Kajian Ideologi Islam Moderat dan Ideologi Islam Radikal}

Menurut M. Sastrapratedja, ideologi secara umum dapat diartikan sebagai seperangkat gagasan atau pemikiran yang berorientasi pada

Contrasting Images and Interpretations (Amsterdam: Amsterdam University Press, 2013), 73-74.

13 Muhammad Ali, Teologi Pluralis-Multikultural: Menghargai Kemajemukan, Menjalin Kebersamaan (Jakarta: Penerbit Buku Kompas, 2003), 122.

${ }^{14}$ Ibid., 115-116.

15 Pendekatan filsafat digunakan untuk membongkar struktur fundamental gagasan pendidikan Muhammadiyah dan NU terkait muatan pendidikan Islam moderatnya. Mengikuti pemikiran Anton Bakker dan Achmad Charris Zubair, kajian ini merupakan model penelitian filsafat aktual, yaitu refleksi filosofis tentang salah satu fenomena dalam situasi aktual, yang dalam hal ini adalah muatan Islam moderat dalam gagasan pendidikan Muhammadiyah dan NU. Lihat Anton Bakker dan Achmad Charris Zubair, Metodologi Penelitian Filsafat (Yogyakarta: Kanisius, 1998), 107-113.

${ }^{16}$ Jajat Burhanudin dan Kees van Dijk (eds.), Islam in Indonesia: Contrasting Images and Interpretations (Amsterdam: Amsterdam University Press, 2013), 11 
tindakan yang terorganisir menjadi suatu sistem yang teratur, ${ }^{17}$ sehingga Richard Pratte menyebut ideologi sebagai "a belief system" yang berhubungan dengan "action". ${ }^{18}$ Dengan ini, ideologi memiliki tiga unsur. Pertama, adanya suatu penafsiran atau pemahaman terhadap kenyataan masa lalu yang diimajinasikan ke masa depan. Kedua, setiap ideologi memuat seperangkat nilai-nilai atau suatu preskripsi moral yang menolak sistem lainnya. Ketiga, ideologi memuat suatu orientasi pada tindakan, yaitu sebagai suatu pedoman untuk mewujudkan nilai-nilai yang termuat di dalamnya. Melalui ketiga unsur ini ideologi berfungsi sebagai pemersatu di antara in group (kita) dan pembeda dengan out group (mereka), karenanya ideologi dapat membentuk identitas kelompok atau bangsa. Ideologi juga berfungsi sebagai futuristik karena memberikan gambaran masa depan yang utopis, di samping juga berfungsi sebagai orientasi pada tindakan. ${ }^{19}$

Di dalam bidang pendidikan, ideologi merupakan sumber kekuasaan dalam mengarahkan pendidikan. ${ }^{20}$ Menurut Gerald L. Gutek, pengarahan dalam pendidikan ini dapat diwujudkan dalam tiga hal; yaitu di dalam menentukan kebijakan dan tujuan pendidikan, di dalam penyampaian nilai-nilai yang tersembunyai (bidden curriculum), dan di dalam formulasi kurikulum itu sendiri. ${ }^{21}$ Ketiga aspek ini senantiasa dipengaruhi dan ditentukan bentuk dan formatnya oleh ideologi pendidikan yang dianut oleh suatu lembaga pendidikan.

Demikian juga di dalam pendidikan Islam, ideologi menjadi sesuatu yang penting untuk memahami pendidikan Islam. Menurut catatan Abdul Ghani 'Abud, "tanpa memahami ideologi Islam, tidak mungkin dapat memahami pendidikan Islam, dan tidak mungkin dapat memahami ideologi Islam tanpa merujuk pada kedua sumbernya, al-Qur'ân dan al-Sunnah. ${ }^{22}$ Jadi, di dalam pendidikan, ideologi merupakan sistem kepercayaan, nilai, atau pandangan serta

\footnotetext{
${ }^{17}$ M. Sastrapratedja, "Pancasila sebagai Ideologi dalam Kehidupan Budaya", dalam Oetojo Oesman dan Alfian (eds.), Pancasaila sebagai Ideologi dalam Berbagai Bidang Kehidupan Bermasyarakat, Berbangsa, dan Bernegara (Jakarta: BP-7 Pusat, 1991), 142.

18 Richard Pratte, Ideology and Education (New York: David McKay Company, 1977), 26-37.

${ }^{19}$ Sastrapratedja, "Pancasila sebagai Ideologi", 143-144.

${ }^{20}$ Lihat H.A.R. Tilaar, Pendidikan dan Kekuasaan: Suatu Tinjauan dari Perspektif Studi Kultural (Magelang: Indonesia Tera, 2003), 120.

${ }^{21}$ Gerald L. Gutek, Philosophical and Ideological Perspectives on Education (New Jersey: Prentice Hall, 1988), 160-162.

22 'Abd al-Ghanî 'Abûd, Fî al-Tarbîyah al-Islâmîyah (t.tp.: Dâr al-Fikr al-'Arabî, 1977), 104.
} 
pemikiran yang menjadi landasan atau orientasi bagi sebuah lembaga pendidikan untuk menentukan langkah-langkah ke mana pendidikan itu mengarah.

Pendidikan Islam di Indonesia dewasa ini telah terfragmentasi dalam beragam ideologi. Lembaga pendidikan di bawah naungan pemerintah, baik berupa madrasah negeri ataupun sekolah negeri, memiliki ideologi yang jelas, yaitu ideologi negara berdasarkan Pancasila. Lain halnya dengan lembaga pendidikan swasta yang dikelola oleh suatu organisasi atau yayasan tertentu, maka ideologi pendidikannya mengikuti ideologi organisasi atau yayasan tersebut. Dalam konteks ini, lembaga pendidikan swasta tak jarang menjadi agen atau penyemai ideologi dari suatu organisasi atau yayasan induknya. Diakui Mardiatmadja, lembaga perguruan swasta senantiasa hadir dengan membawa identitas dan ciri khasnya sendiri. Identitas ini merupakan simbol yang menunjukkan eksistensinya. Harga diri suatu perguruan swasta sangat tergantung pada identitasnya; termasuk segala kelebihan dan kekurangannya, serta keunikannya yang tidak dimiliki oleh pihak mana pun, kecuali oleh dirinya sendiri. ${ }^{23}$ Identitas kekhasan ini tentu saja dibalut oleh baju bernama ideologi. Oleh karena itu, untuk melihat muatan pendidikan suatu lembaga pendidikan Islam swasta, dapat dilacaknya melalui ideologi lembaga induknya.

Sebuah lembaga pendidikan Islam dapat dikategorikan pengusung Islam moderat, manakala organisasi atau lembaga induknya memiliki ideologi Islam berpaham moderat. Sebaliknya, suatu lembaga pendidikan Islam dapat dikategorikan pengusung Islam radikal, manakala organisasi atau lembaga induknya memiliki ideologi Islam berpaham radikal. Dari sini diperlukan pemahaman yang jelas antara Islam berideologi moderat dengan Islam berideologi radikal.

Menurut KBBI Offline Versi $1.5,{ }^{24}$ terma "moderat" memiliki dua makna, yaitu: (1) selalu menghindarkan perilaku atau pengungkapan yang ekstrem; dan (2) berkecenderungan ke arah dimensi atau jalan

23 Mardiatmadja, "Peran Perguruan Swasta: Khususnya Perguruan Katolik dalam Pendidikan Nasional" (dalam http://www.mardiatmadja.org/Tulisan Lepas Perguruan Swasta.htm, diakses 20 Februari 2010).

24 KBBI Offline Versi 1.5 merupakan KBBI (Kamus Besar Bahasa Indonesia) Luar Jaringan (Offline) lansiran 2010-2013, yang mengacu pada data dari KBBI Daring (Dalam Jaringan atau Online) Edisi III yang diambil dari http://pusatbahasa.kemdiknas.go.id/kbbi/. Software ini merupakan Freeware yang dikembangkan oleh Ebta Setiawan. 
tengah. ${ }^{25}$ Oleh karena itu, paham moderat berarti paham yang tidak ekstrem, dalam arti selalu cenderung pada jalan tengah. Al-Qur'ân menyebut umat Islam sebagai ummah wasata (Q.S. al-Baqarah: 143), yaitu umat "tengahan", "moderat", adil, dan "terbaik". Oleh karena itu, mengedepankan sikap moderat bukan hanya berkesesuaian dengan anjuran ayat ini (dan ayat-ayat al-Qur'ân lainnya yang senafas), tapi juga menjadi karakter utama umat ini. Dari sini, Muchlis M. Hanafi memaknai moderat (al-wasat) sebagai metode berpikir, berinteraksi dan berperilaku secara tawẫun (seimbang) dalam menyikapi dua keadaan, sehingga ditemukan sikap yang sesuai dengan prinsip-prinsip Islam dan tradisi masyarakat, yaitu seimbang dalam akidah, ibadah dan akhlak. ${ }^{26}$

Dengan mengutip pandangan John L. Esposito, Masdar Hilmy menyebutkan bahwa terma "moderat" dan "moderatisme" merupakan nomenklatur konseptual yang sulit didefinisikan. Terma ini diperebutkan oleh kelompok agama ataupun para ilmuwan, sehingga dimaknai secara berbeda-beda, tergantung siapa dan dalam konteks apa ia dipahami. ${ }^{27}$ Kesulitan pemaknaan ini disebabkan karena khazanah pemikiran Islam Klasik tidak mengenal istilah "moderatisme". Penggunaan dan pemahaman atasnya biasanya merujuk pada padanan sejumlah kata dalam bahasa Arab, di antaranya al-tawassut atau al-wasat (moderasi), al-qist. (keadilan), al-tawẫun (keseimbangan), al-itidâl (keselarasan/kerukunan), dan semacamnya. ${ }^{28}$ Namun demikian, dalam konteks Indonesia, masih menurut Hilmy, terdapat beberapa karakteristik moderatisme Islam. Hilmy menyatakan:

"The concept of moderatism in the context of Indonesian Islam has at least the following characteristics; 1) non-violent ideology in propagating Islam; 2) adopting the modern way of life with its all derivatives, including science and technology, democracy, human rights and the like; 3) the use of rational way of thinking; 4) contextual approach in understanding Islam, and; 5) the use of ijtihâd (intellectual exercises to make a legal opinion in case of the

25 "Moderat" dalam KBBI Offline Versi 1.5.

${ }^{26}$ Muchlis M. Hanafi, Moderasi Islam: Menangkal Radikalisasi Berbasis Agama (Jakarta: Ikatan Alumni al-Azhar dan Pusat Studi al-Qur'ân, 2013), 3-4

27 Masdar Hilmy, "Whither Indonesia's Islamic Moderatism? A Reexamination on the Moderate Vision of Muhammadiyah and NU", Journal of Indonesian Islam, Vol. 07, Number 01, June 2013, 25.

${ }^{28}$ Ibid., 27. 
absence of explicit justification from the Qur'ân and Hadîth). Those characteristics are, however, can be expanded into several more characteristics such as tolerance, harmony and cooperation among different religious groups". ${ }^{29}$

Sementara itu, untuk konteks Indonesia, Muhammad Ali memaknai Islam moderat sebagai "those who do not share the hardline visions and actions". ${ }^{30}$ Dengan pemaknaan ini, ia menyatakan bahwa Islam moderat Indonesia merujuk pada komunitas Islam yang menekankan pada perilaku normal (tawassut) di dalam mengimplementasikan ajaran agama yang mereka tegakkan; mereka toleran terhadap perbedaan pendapat, menghindari kekerasan, dan memrioritaskan pemikiran dan dialog sebagai strateginya. Dengan ini, mereka adalah mainstream Islam Indonesia, meskipun gerakan strategisnya untuk memoderasi keagamaan dan politik masih dinilai terbatas. Gagasan-gagasan semisal "Islam Pribumi", "Islam Rasional", "Islam Progresif", "Islam Transformatif", "Islam Liberal", "Islam Inklusif", "Islam Toleran", dan "Islam Plural”, yang muncul sejak tahun 1970-an dapat dikategorikan sebagai Islam moderat Indonesia. Kategori yang sama juga dapat disematkan pada gagasan-gagasan reaktualisasi Islam, nasionalisasi Islam, desakralisasi budaya Islam, atau ijtihad kontekstual. ${ }^{31}$

Berbeda dengan Muhammad Ali yang lebih menekankan pada substansi karakter Islam moderat, Ahmad Najib Burhani memaknai Islam moderat untuk Indonesia lebih pada makna bahasanya, yaitu sebagai "mid-position between liberalism and Islamism". Orang atau organisasi yang berada di tengah-tengah antara liberalisme dan Islamisme adalah moderat. ${ }^{32}$ Dengan demikian, bagi Burhani, Islam moderat Indonesia adalah bukan liberal dan juga bukan Islamis.

Dari beberapa pandangan mengenai Islam moderat di atas, untuk konteks Indonesia, penulis lebih setuju pada hakikat atau substansi Islam moderat, yang oleh al-Qur'ân disebut sebagai raḥmah li al-âlamîn (Q.S. al-Anbiyâ: 107). Dengan pemaknaan ini, Islam moderat bagi

\footnotetext{
${ }^{29}$ Ibid., 28.

${ }^{30}$ Muhammad Ali, "Moderate Islam Movement in Contemporary Indonesia" dalam Rizal Sukma dan Clara Joewono (eds.), Islamic Thoughts and Movements in Contemporary Indonesia (Jakarta: Center for Strategic and International Studies, 2007), 198.

31 Ibid., 199.

32 Ahmad Najib Burhani, "Pluralism, Liberalism and Islamism: Religious Outlook of the Muhammadiyah Islamic Movement in Indonesia" (Tesis--Fakulty of Humanities, University of Manchester, 2007), 16.
} 
Indonesia adalah Islam yang bukan ekstrem atau radikal, yang senantiasa tidak menekankan pada kekerasan atau tidak menempuh garis keras di dalam mengimplementasikan keberislamannya. Kelompok Islam liberal atau kelompok Islamis, selama mereka menempuh jalur yang bukan rahmah, maka itu bukan dikategorikan Islam moderat. Dengan ini, Islam moderat ditandai dengan beberapa karakteristik, yaitu berperilaku normal (tawassut) di dalam mengimplementasikan ajaran agama; toleran terhadap perbedaan pendapat, menghindari kekerasan, memrioritaskan dialog, mengakomodir konsep-konsep modern yang secara substansial mengandung maslahat, berpikir rasional berdasarkan wahyu, menafsirkan teks secara kontekstual, dan menggunakan ijtihad di dalam menafsirkan apa yang tidak termaktub di dalam al-Qur'ân atau Sunnah. Dengan karakter ini, Islam moderat adalah mereka yang memiliki sikap toleran, rukun dan kooperatif dengan kelompokkelompok agama yang berbeda. Inilah watak rahmah bagi Islam moderat Indonesia, yang lebih bermakna teologis, daripada politis yang sering diwacanakan oleh Amerika Serikat ketika memaknai Islam moderat. ${ }^{33}$

Dengan watak seperti itu, Islam moderat merupakan kebalikan dari Islam radikal, ${ }^{34}$ yang untuk kemudian sering disebut sebagai fundamentalisme, militanisme, fanatisme, Islamisme atau ekstremisme. ${ }^{35}$ Menurut KBBI Offline Versi 1.5, terma "radikal" adalah kata adjektif yang berarti "secara mendasar atau sampai kepada yang prinsip". Kata ini sering digunakan dalam bidang politik, yang biasanya diartikan sebagai "amat keras menuntut perubahan undangundang atau pemerintahan". ${ }^{36}$ Dari kata "radikal" ini muncul kata "radikalisasi" yang mengandung arti "proses, cara atau perbuatan

\footnotetext{
${ }^{33}$ Lihat pemaknaan Islam moderat yang teologis, bukan politis, oleh Ahmad Najib Burhani, "Al-Tawassut wa-l I'tidal: the NU and Moderatism in Indonesian Islam", Asian Journal of Social Science, Vol. 40, Issue 5-6 (2012), 564-581.

${ }^{34}$ Dari sini kedua istilah ini sering dipersandingkan sebagai sebuah terma yang saling diperlawankan. Informasi awal tentang Islam moderat versus Islam radikal, lihat misalnya Nurjannah, Radikal vs Moderat: Atas Nama Dakwah, Amar Makruf Nabi Mungkar dan Jihad Perspektif Psikologi (Yogyakarta: Aswaja Presindo, 2013). Buku ini berasal dari disertasi penulisnya di Fak. Psikologi UGM.

35 Lihat A. Rubaidi, Radikalisme Islam: Nabdlatul Ulama dan Masa Depan Moderatisme Islam di Indonesia (Surabaya: PWNU Jawa Timur, 2010), 31-32.

36 "Radikal" dalam KBBI Offline Versi 1.5.
} 
menjadikan radikal", dan kata "radikalisme" dengan arti "paham atau aliran yang radikal dalam politik yang menginginkan perubahan atau pembaharuan sosial dan politik dengan cara kekerasan atau drastis, sehingga dipandang sebagai sikap ekstrem dalam aliran politik". ${ }^{38}$ Dari pengertian-pengertian di atas, secara bahasa dapat dikatakan bahwa paham keagamaan Islam radikal mengandung arti aliran, haluan atau pandangan yang berhubungan dengan agama Islam, yang secara politis amat keras menuntut perubahan undangundang atau pemerintahan.

Terkait dengan itu, KH. Hasyim Muzadi pada Seminar Nasional bertema "Deradikalisasi Agama melalui Peran Muballigh di Jawa Tengah" yang diselenggarakan oleh Fakultas Dakwah IAIN Walisongo bekerja sama dengan Direktorat Jenderal Informasi dan Komunikasi Publik, Kementerian Komunikasi dan Informasi, tanggal 20 Juli 2011 di Hotel Novotel Semarang, mengatakan bahwa pada dasarnya seseorang yang berpikir radikal (yaitu berpikir mendalam, sampai ke akar-akarnya) boleh-boleh saja, karena memang berpikir sudah seharusnya seperti itu. Seseorang yang dalam hatinya berpandangan bahwa Indonesia mengalami banyak masalah, karena Indonesia tidak menerapkan syariat Islam, karena itu dasar negara Indonesia harus diganti dengan sistem pemerintahan Islam (khilâfah Islamîah) misalnya, maka pendapat radikal seperti ini sah-sah saja. Sekeras apapun suatu pernyataan, jika hanya dalam wacana atau pemikiran, tidak akan termasuk tindak pidana. Kejahatan adalah suatu tindakan (omissi). Dalam pengertian ini, seseorang tidak dapat dihukum hanya karena pikirannya, melainkan harus ada suatu tindakan atau kealpaan dalam bertindak. Berpikir radikal seperti ini akan meningkat menjadi radikalisme, yaitu radikal dalam paham atau ismenya, yang biasanya akan menjadi radikal secara permanen. Dengan kata lain, radikalisme adalah radikal yang sudah menjadi ideologi dan mazhab pemikiran. Sedangkan radikalisasi adalah (seseorang yang) tumbuh menjadi reaktif, ketika terjadi ketidakadilan di masyarakat. Biasanya radikalisasi tumbuh berkaitan dengan ketikadilan ekonomi, politik, lemahnya penegakan hukum dan seterusnya. Jangan dibayangkan ketika teroris sudah ditangkap, lalu radikalisme hilang. Sepanjang keadilan dan kemakmuran belum terwujud, radikalisasi akan selalu muncul di masyarakat. Dengan

37 "Radikalisasi" dalam KBBI Offline Versi 1.5.

38 "Radikalisme" dalam KBBI Offline Versi 1.5. 
demikian, potensi berpikir, bersikap dan bertindak radikal, sehingga menjadi ideologi radikal (radikalisme), kemudian tumbuh secara reaktif menjadi radikal (radikalisasi), adalah modal awal seseorang menjadi pelaku teror (teroris) atau orang yang berpaham teror (terorisme). Tidak ada teror tanpa radikalisme, sebaliknya, penganut radikalisme belum tentu menyukai jalan kekerasan (teror). ${ }^{39}$

Pandangan Muzadi di atas diamini oleh Arsyad Mbai, mantan Kepala BNPT. Dalam sebuah wawancara dengan majalah Tempo, Arsyad Mbai menyatakan bahwa radikalisme adalah akar dari terorisme. Menurutnya, ideologi radikal adalah penyebab dari maraknya aksi teror di Indonesia, sehingga pencegahan terorisme harus diikuti oleh pemberantasan radikalisme. Secara spesifik, Mbai melihat adanya ideologi tersebut dalam perilaku teror di masyarakat sejak tahun 2000 -an. ${ }^{40}$

Dalam pandangan Noorhaidi Hasan, sesuatu dikatakan radikal jika mengabsahkan penggunaan metode kekerasan dalam upaya mewujudkan perubahan radikal dalam sistem politik ataupun masyarakat. Dengan demikian, ukuran radikalisme terletak pada kecenderungan mengupayakan perubahan radikal terhadap sistem yang ada dengan menggunakan kekerasan. Radikalisme bisa dinisbatkan kepada pemikiran, gagasan, aksi, atau gerakan dari agama apa saja. Ketika radikalisme itu didasari oleh semangat menggantikan sistem yang ada dengan sistem baru yang bersumber dari shari $a h$, maka ini disebut radikalisme Islam. Apabila radikalisme itu dipoles dengan doktrin-doktrin jihad, dalam arti pengesahan kekerasan itu dengan dalih jihad, maka disebut jihadisme. Dari jihadisme inilah berkembang terorisme Islam, atau lebih tepatnya, terorisme atas nama Islam. Inilah puncak aksi kekerasan. ${ }^{41}$

Sementara itu, menurut Endang Turmudi dan Riza Sihbudi, radikalisme keagamaan sebenarnya merupakan fenomena yang bisa muncul dalam setiap agama, karena ia adalah semacam ideologi yang menjadikan agama sebagai pegangan hidup oleh masyarakat maupun individu. Fundamentalisme ini pada gilirannya akan diiringi

\footnotetext{
39 Dikutip dari Abu Rokhmad, "Radikalisme Islam dan Upaya Deradikalisasi Paham Radikal", Walisongo: Jurnal Penelitian Sosial Keagamaan, Volume 20, Nomor 1 (2012), 82-83.

40 Dikutip dari Ahmad Rizky Mardhatillah Umar, "Melacak Akar Radikalisme Islam di Indonesia”, Jurnal Ilmu Sosial dan Ilmu Politik, Vol. 14, Nomor 2 (2010), 171.

${ }^{41}$ Noorhaidi Hasan, Islam Politik di Dunia Kontemporer: Konsep, Genealogi, dan Teori (Yogyakarta: Suka-Press, 2012), 23-26.
} 
radikalisme dan kekerasan, apabila upaya semangat kembali pada dasar-dasar agama tadi mendapat rintangan dari situsai politik yang mengelilinginya. Radikalisme sebenarnya tidak menjadi masalah, selama ia hanya bersarang dalam pemikiran yang bersifat ideologis dalam diri penganutnya. Akan tetapi, ketika radikalisme ideologis itu bergeser dari wilayah pemikiran ke wilayah gerakan, maka ia mulai akan menimbulkan masalah, utamanya ketika semangat untuk kembali pada dasar-dasar agama itu dihalangi oleh kekuatan politik lain. Dalam situasi ini, radikalisme tak jarang akan diiringi kekerasan atau terorisme. ${ }^{42}$ Dari pergeseran inilah orang sering memaknai radikalisme dalam dua wujud, yaitu radikalisme dalam pikiran yang disebut fundamentalisme; dan radikalisme dalam tindakan yang disebut terorisme. ${ }^{43}$

Dalam konteks itu, menurut Rahimi Sabirin, radikalisme merupakan pemikiran atau sikap keagamaan yang ditandai empat hal. Pertama, sikap tidak toleran, tidak mau menghargai pendapat dan keyakinan orang lain. Kedua, sikap fanatik, yaitu selalu merasa benar sendiri, menganggap orang lain salah. Ketiga, sikap eksklusif, yaitu membedakan diri dari kebiasaan umat kebanyakan. Keempat, sikap revolusioner, yaitu cenderung menggunakan kekerasan untuk mencapai tujuan. ${ }^{44}$

Secara khusus dalam Islam, Greg Fealy dan Virginia Hooker dalam pengantar editornya menyatakan bahwa:

"Radical Islam refers to those Islamic movements that seek dramatic change in society and the state. The comprehensive implementation of Islamic law and the upholding of "Islamic norms", however defined, are central elements in the thinking of most radical groups. Radical Muslims tend to have a literal interpretation of the Qur'ân, especially those sections relating to social relations, religious behavior and the punishment of crimes, and they also seek to adhere closely to the perceived normative model based on the example of the Prophet Muhammad". ${ }^{45}$

Sementara itu, Yûsuf al-Qaradawî menyebut empat indikator bagi religious extremism. Pertama, fanatisme dan intoleransi, sebagai akibat

${ }^{42}$ Endang Turmudi dan Riza Sihbudi, Islam dan Radikalisme di Indonesia (Jakarta: LIPI Press, 2005), 4-5.

${ }^{43}$ Lihat Rahimi Sabirin, Islam dan Radikalisme (Yogyakarta: Ar-Rasyid, 2004), 6.

44 Ibid., 5.

45 Greg Fealy dan Virginia Hooker (eds.), Voices of Islam in Southeast Asia: A Contemporary Sourcebook (Singapore: ISEAS, 2006), 4. 
dari prasangka (prejudice), kekakuan (rigidity), dan kepicikan pandangan (lack of insight). Sikap ini menggiring mereka untuk memaksa orang lain, baik dalam bentuk terorisme intelektual seperti fitnah dan tuduhan terhadap penganut bid'ah, dan sebagainya, maupun dalam bentuk terorisme fisik yang lebih terrifying. Kedua, berlebih-lebihan atau melampaui batas, sehingga cenderung mengambil garis keras (hard-line) yang hobi berdemonstrasi dengan makian, hasutan dan bahkan ancaman bom. Ketiga, membebani orang lain tanpa memertimbangkan situasi dan kondisi. Keempat, keras dalam memerlakukan diri sendiri dan orang lain, sehingga misalnya, asas praduga tak bersalah tidak pernah dihiraukan. Semua ciri ekstremisme agama yang tiranik dan tidak egaliter ini, jelas membahayakan hak-hak orang lain, yang dapat melahirkan bahaya dan ketidakamanan. ${ }^{46}$

Dari paparan di atas, dapat diketahui bahwa Islam radikal adalah paham, ideologi, atau keyakinan keagamaan Islam yang bermaksud melakukan perubahan masyarakat dan negara secara radikal, yaitu mengembalikan Islam sebagai pegangan hidup bagi masyarakat maupun individu. Oleh karena perubahan ini dilakukan secara radikal, maka bagi paham ini, memungkinkan dilakukannya tindakan radikalisme, apabila upaya semangat kembali pada dasar-dasar fundamental Islam ini mendapat rintangan dari situsai politik yang mengelilinginya. Dengan keyakinan yang kuat terhadap ideologinya yang dianggapnya benar, paham keagamaan Islam radikal lahir sebagai sebuah respons terhadap kondisi yang menurutnya bertentangan dengan keyakinannya, bahkan sekuat tenaga akan merubahnya secara terus-menerus apabila tatanan yang ada belum sepenuhnya sesuai dengan tatanan yang diharapkannya.

Dengan demikian, kiranya dapat ditarik benang merah mengenai karakteristik Islam radikal. Pertama, menghendaki pelaksanaan hukum Islam dan penegakan norma-norma Islam secara komprehensif dalam kehidupan individu dan masyarakat, sesuai apa yang dimodelkan oleh Rasulullah, sehingga memiliki sikap keberagamaan yang fanatik. Menurut Masdar Hilmy, karakter ini mengindikasikan bahwa paham Islam radikal adalah totalitarian. Sebagai anti-tesis terhadap paham Barat, paham Islam radikal menekankan adanya visi Islam sebagai doktrin agama dan sebagai praktik sosial sekaligus. Paham integrasi ini sering disebut sebagai "Tiga D", yaitu bahwa Islam menyatukan antara Dîn, Dunyâ, dan Dawlah, karena seluruh aspek kehidupan

${ }^{46}$ Dikutip dari Ali, Teologi Pluralis-Multikultural, 107-108. 
manusia sudah tercover oleh al-Qur'ân dan Sunnah. Puncak dari keyakinan ini adalah pendirian "negara Islam" yang mengatur semua kehidupan individu berdasarkan konsep sharî‘ah. ${ }^{47}$ Kedua, menafsirkan ayat-ayat al-Qur'ân yang berkaitan dengan hubungan sosial, perilaku keagamaan dan hukuman kejahatan secara literal-tekstual. Penafsiran rasional-kontekstual terhadap al-Qur'ân tidak diperlukan sepanjang alQur'ân telah menyatakannya secara eksplisit. Oleh karena itu, paham ini tidak menyatakan apa yang tidak dimunculkan al-Qur'ân, yang dinilainya sebagai bid'ah, bahkan konsep-konsep Barat semisal demokrasi, liberalisme dan kapitalisme adalah bid'ah, karena itu haram menurut Islam. Di sini, penggunaan simbol-simbol Islam menjadi karakter determinan paham ini, pada saat yang sama pemurnian Islam menjadi teologi yang dipertahankan. ${ }^{48}$ Ketiga, model penafsiran literaltekstual ini membawanya untuk bersikap intoleransi terhadap semua paham atau keyakinan yang bertentangan dengannya, dan pada saat yang sama bersikap eksklusif dengan membedakan diri dari orang kebanyakan. Di dalam sikap seperti ini, dunia hanya berisi dua hal, yaitu baik-buruk, halal-haram, iman-kufur, dan seterusnya, dengan mengabaikan ketentuan-ketentuan hukum lain, semisal sunnah, makruh, dan mubah. Adapun sikap eksklusif muncul karena "menutup" atas pengaruh luar yang dinyatakannya sebagai ketidakbenaran. Kebenaran yang diyakininya ini akan dipertahankan, sekalipun harus meneteskan darah. ${ }^{49}$ Keempat, intoleransi dan eksklusivitas hasil dari penafsiran di atas menghasilkan pandangan yang revolusioner, yaitu ingin merubah secara terus-menerus, sehingga memungkinkan dilakukannya tindakan kekerasan, selama tujuan yang diinginkan belum tercapai.

Pada dasarnya, keyakinan atau ideologi yang dimiliki oleh kelompok Islam radikal mempunyai beberapa landasan konseptual, seperti konsep tentang kebangkitan Islam, menyerukan kebaikan dan memerangi kejahatan, berjuang di jalan Allah (jihad), membangun kembali komunitas seperti zaman Nabi Muhammad, dan keinginan menerapkan hukum Islam sebagai basis keadilan sosial dalam bangunan teologi Islam. Berdasarkan cita-cita dan sikap keyakinan ini, Islam radikal mempunyai banyak tema, yaitu pembuktian prasangka

47 Masdar Hilmy, "The Politics of Retaliation: the Backlash of Radical Islamists to Deradicalization Project in Indonesia", Al-jâmi ab: Journal of Islamic Studies, Vol. 51, No. 1 (2013), 133.

48 Ibid., 134 dan 136.

${ }^{49}$ Ibid., 134. 
global untuk mendirikan negara Islam, penyelesaian atas kesiapan untuk menjalankan hukum Islam guna melawan penindasan Barat, dan klaim sebagai satu-satunya Islam yang autentik dan genuine. Untuk mewujudkan keyakinan ini, mereka senantiasa menyerukan dan mengajak jihad ke segenap umat Islam, meski dengan jalan kekerasan..$^{50}$

Ideologi Islam di atas, baik yang moderat maupun yang radikal, senantiasa disemaikan, dikuatkan dan dilestarikan melalui berbagai media dan sarana. Salah satu media yang sangat startegis bagi penguatan dan penyemaian ideologi Islam moderat atau radikal adalah melalui jalur pendidikan. Menurut Syamsul Arifin, peran dunia pendidikan dapat diplot sebagai salah satu institusi yang dapat dioptimalisir untuk melakukan apa yang disebut dengan deradikalisasi. Peran pendidikan terutama yang dikelola oleh umat Islam diharapkan dapat melakukan peran tersebut, bersama institusi lainnya, sehingga wajah Islam di Indonesia tetap terlihat ramah, toleran, moderat, namun tetap memiliki martabat di mata dunia. ${ }^{51}$

Dengan demikian, untuk menakar ulang apakah Muhammadiyah dan NU yang dicap sebagai "gembong" Islam moderat bagi Indonesia itu, berusaha menyemaikan ideologi Islam moderatnya melalui gagasan-gagasan pendidikan Islam moderatnya? Dalam konteks ini, menarik untuk mengangkat pandangan Muhammad Ali yang berpendapat bahwa ideologi Islam moderat dapat disemaikan melalui model pendidikan pluralis-multikultural. Menurutnya, wawasan pluralis-multikultural dalam pendidikan agama merupakan bekal penting agar kalangan pelajar mampu menghargai perbedaan, menghormati secara tulus, komunikatif, terbuka, dan tidak saling curiga, selain untuk meningkatkan iman dan takwa. Pendidikan pluralis-multikultural bukanlah mengajarkan anak didik untuk menjalankan agama dengan seenaknya sendiri, tanpa tanggung jawab dan ketulusan, tetapi justru mengajarkan untuk taat beragama, tanpa menghilangkan identitas keagamaan masing-masing. Wajah agama yang ditampilkan pendidikan pluralis-multikultural adalah agama yang moderat dan ramah. ${ }^{52}$

\footnotetext{
50 Ahmad Fuad Fanani, “Akar Radikalisme dan Terorisme”, Suara Merdeka, Jum'at, 07 Oktober 2005.

51 Syamsul Arifin, "Membendung Arus Radikalisasi di Indonesia", Islamica, Vol. 8, Nomor 2 (2014), 416.

52 Ali, Teologi Pluralis-Multikultural, 102.
} 
Dengan demikian, keberadaan pendidikan Islam moderat ini menjadi penting untuk konteks Indonesia, di tengah-tengah maraknya berbagai ideologi radikal yang masuk ke Indonesia melalui jaringan transnasinal. Pada Rapat Terbatas tanggal 5 Juni 2015 di Istana Bogor, Presiden Joko Widodo mengundang MUI, ormas-ormas Islam dan rektor sejumlah UIN di Indonesia, untuk menggagas pendidikan Islam moderat di Indonesia. Dalam kesempatan itu, Presiden menegaskan bahwa Islam Indonesia adalah Islam yang moderat yang rukun dan selalu rukun berdampingan dengan agama lainnya, dan ini merupakan sebuah cermin Islam yang bukan hanya menimbulkan citra yang baik terhadap bangsa Indonesia yang plural, tetapi juga raḥmah li al-âlamîn. Untuk itu, diperlukan sebuah perguruan tinggi Islam yang moderat. "Perguruan tinggi Islam moderat yang betulbetul sebuah universitas yang besar, yang nanti akan menjadi kiblat perguruan tinggi Islam," ${ }^{53}$ demikian tegas Joko Widodo.

\section{Gagasan Islam Moderat Lembaga Pendidikan Muhammadiyah}

Muhammadiyah yang didirikan oleh Ahmad Dahlan pada 18 Dzulhijjah $1330 \mathrm{H}$, atau bertepatan dengan 12 Nopember $1912 \mathrm{M}$ di Yogyakarta, ${ }^{54}$ sering dicap banyak kalangan sebagai organisasi Islam yang berwawasan Islam moderat. Pandangan moderatisme Muhammadiyah ini misalnya terlihat dalam kajian yang dilakukan oleh Ahmad Najib Burhani mengenai sikap religius Muhammadiyah mengenai pluralisme, liberalisme dan Islamisme. ${ }^{55}$ Demikian juga kajian Muhammad Ali yang telah memasukkan Muhammadiyah sebagai komunitas Muslim Indonesia yang berwajah moderat. ${ }^{56}$ Dalam konteks ini, Tafsir, Sekretaris PW. Muhammadiyah Jawa Tengah mengungkapkan:

"Muhammadiyah ingin menampilkan wajah Islam yang murni namun ramah, maju dan moderat sebagaimana digambarkan

\footnotetext{
53 Silakan akses "Jokowi Ingin Bangun Universitas Islam Moderat" dalam http://www.pikiran-rakyat.com/pendidikan/2015/06/05/329989/jokowi-inginbangun-universitas-islam-moderat (diakses pada 13 Juni 2015) dan "Jokowi Ingin Pertahankan Pendidikan Islam Moderat" dalam http://nasional.news.viva.co.id /news/read/634595-jokowi-ingin-pertahankan-pendidikan-islam-moderat (diakses pada 13 Juni 2015).

54 Tentang sejarah pendirian Muhammadiyah oleh Ahmad Dahlan, lihat misalnya Toto Suharto, Filsafat Pendidikan Islam: Menguatkan Epistemologi Islam dalam Pendidikan (Yogyakarta: Ar-Ruzz Media, 2014), 244-250.

${ }^{55}$ Burhani, "Pluralism, Liberalism, and Islamism", 49-55.

${ }^{56}$ Ali, "Moderate Islam Movement", 204-209.
} 
dalam al-Qur'ân, rahmat bagi sekalian alam. Di samping itu, ia juga ingin bagaimana Islam menjadi tuan rumah di negeri ini di mana Islam benar-benar menyatu dan mengakar dalam budaya masyarakat Indonesia. Maka satu langkah yang ditempuhnya adalah membangun dakwah yang lebih manusiawi dan mudah diterima masyarakat". ${ }^{7}$

Untuk itu, pada Tanwir Muhammadiyah di Bandung tahun 2012, telah diputuskan mengenai "Kristalisasi Ideologi dan Khittah Muhammadiyah", yang salah satu keputusannya menyebutkan bahwa ideologi Muhammadiyah ialah "ideologi Islam yang berkemajuan yang memandang Islam sebagai Dîn al-Ḥadârah. Ideologi berkemajuan ini ditandai dengan beberapa karakter, yaitu tajdîd dalam rangka pembaruan kembali kepada al-Qur'ân dan Sunnah dengan mengembangkan ijtihâd; bercorak reformis-modernis dengan sifat wasatîyah (tengah, moderat) untuk membedakannya dari ideologiideologi lain yang serba ekstrem; mengedepankan sikap prokemajuan dan anti-kejumudan, properdamaian dan anti-kekerasan, prokeadilan dan anti-penindasan, prokesamaan dan anti-dikriminasi; serta menjunjung tinggi nilai-nilai utama yang autentik sesuai jiwa ajaran Islam. $^{58}$

Menurut Haedar Nashir, maksud dari "ideologi Islam yang berkemajuan" adalah bahwa Muhammadiyah berupaya menampilkan corak Islam yang memadukan antara purifikasi dengan dinamisasi, dan bersifat moderat (wasatiyah) dalam meyakini, memahami, dan melaksanakan ajaran Islam. Muhammadiyah dengan watak ini berbeda dengan karakter gerakan-gerakan Islam lain yang cenderung ekstrem, baik yang bersifat radikal-fundamentalis ataupun radikal-liberal. Ideologi moderat ini bukanlah paham yang tidak jelas, lembek dan plin-plan, karena Muhammadiyah dalam paham dan sikap keagamaannya memiliki prinsip yang tegas, lugas, dan kuat sebagaimana manhaj gerakan Muhammadiyah. ${ }^{59}$ Ideologi dengan karakter moderat ini mengindikasikan bahwa Muhammadiyah berbeda dengan gerakan Islam radikal-liberal yang serba liberal dalam melakukan dekonstruksi atas ajaran Islam sehingga serba relatif; dan

57 Tafsir, "Simpang Jalan-Simpang Jalan Muhammadiyah", Maarif, Vol. 4, No. 2 (2009), 28.

58 Lihat Haedar Nashir, Memahami Ideologi Muhammadiyah (Yogyakarta: Suara Muhammadiyah, 2015), 183.

${ }^{59}$ Ibid., 61-62. 
pada saat yang sama berbeda dengan gerakan radikal-fundamentalis semisal Salafi, Wahabi, Tarbiyah/al-Ikhwân al-Muslimûn, Taliban, Jemaah Tabligh, Islam Jemaah, Jemaah Islamiyah, Hizbut Tahrir, Majelis Mujahidin, Ansharut Tauhid, Islam Tradisional, Majelis Tafsir al-Qur'ân, dan kelompok Shî‘'ah. ${ }^{60}$

Itulah ideologi Muhammadiyah dengan watak moderat, dalam arti tengahan antara liberalisme dan radikalisme. Pertanyaannya, apakah ideologi moderat ini juga disemaikan dalam lembaga-lembaga pendidikannya? Selain berdakwah, cita-cita utama Muhammadiyah adalah mementingkan pendidikan dan pengajaran yang berdasarkan ajaran Islam, baik pendidikan di sekolah/madrasah ataupun pendidikan dalam masyarakat. Dalam bidang pendidikan, hingga tahun 2010 Muhammadiyah memiliki 4.623 Taman Kanak-Kanak; 6.723 Pendidikan Anak Usia Dini; 15 Sekolah Luar Biasa; 1.137 Sekolah Dasar; 1.079 Madrasah Ibtidaiyah; 347 Madrasah Diniyah; 1.178 Sekolah Menengah Pertama; 507 Madrasah Tsanawiyah; 158 Madrasah Aliyah; 589 Sekolah Menengah Atas; 396 Sekolah Menengah Kejuruan; 7 Muallimin/Muallimat; 101 Pondok Pesantren; serta 3 Sekolah Menengah Farmasi. Dalam bidang pendidikan tinggi, sampai tahun 2010, Muhammadiyah memiliki 40 Universitas, 93 Sekolah Tinggi, 32 Akademi, serta 7 Politeknik. ${ }^{61}$

Dari data di atas, tampak bahwa Muhammadiyah dewasa ini memiliki sejumlah lembaga pendidikan, mulai dari jenjang PAUD, dasar dan menengah, hingga jenjang pendidikan tinggi, mulai dari madrasah hingga sekolah, mulai dari formal hingga nonformal. Menurut Lampiran VI Keputusan Muktamar Muhammadiyah Ke-46 tentang Revitalisasi Pendidikan Muhammadiyah, sebagaimana dimuat dalam Tanfidz Keputusan Muktamar Satu Abad Mubammadiyah: Muktamar Muhammadiyah Ke-45, visi pendidikan Muhammadiyah adalah "Terbentuknya manusia pembelajar yang bertaqwa, berakhlak mulia, berkemajuan dan unggul dalam IPTEKS sebagai perwujudan tajdîd dakwah amar ma'rûf naby munkar?. ${ }^{2}$

\footnotetext{
${ }^{60}$ Ibid., 57.

61 Lihat Tanfidz Keputusan Muktamar Satu Abad Mubammadiyah: Muktamar Muhammadiyah Ke-45 (Yogyakarta: Pusat Pimpinan Muhammadiyah, 2010), 37.

62 Lampiran VI Keputusan Muktamar Muhammadiyah Ke-46 tentang Revitalisasi Pendidikan Muhammadiyah, sebagaimana dimuat dalam Tanfidz Keputusan Muktamar Satu Abad Mubammadiyah: Muktamar Muhammadiyah Ke-45 (Yogyakarta: Pusat Pimpinan Muhammadiyah, 2010), 128.
} 
Untuk mewujudkan visi itu, ada enam nilai dasar yang dibangun dalam pendidikan Muhammadiyah. Pertama, pendidikan Muhammadiyah diselenggarakan merujuk pada nilai-nilai yang bersumber pada al-Qur'ân dan Sunnah. Kedua, rûh al-ikhlâs untuk mencari rida Allah menjadi dasar dan inspirasi dalam ikhtiar mendirikan dan menjalankan amal usaha di bidang pendidikan. Ketiga, menerapakan prinsip kerjasama (mushârakah) dengan tetap memelihara sikap kritis, baik pada masa Hindia Belanda, Dai Nippon (Jepang), Orde Lama, Orde Baru hingga pasca Orde Baru. Keempat, selalu memelihara dan menghidup-hidupkan prinsip pembaruan (tajdîd), inovasi dalam menjalankan amal usaha di bidang pendidikan. Kelima, memiliki kultur untuk memihak kepada kaum yang mengalami kesengsaraan (du'afâ dan mustad'afin) dengan melakukan proses-proses kreatif sesuai dengan tantangan dan perkembangan yang terjadi pada masyarakat Indonesia. Keenam, memerhatikan dan menjalankan prinsip keseimbangan (tawassut atau moderat) dalam mengelola lembaga pendidikan antara akal sehat dan kesucian hati. ${ }^{63}$

Dari enam nilai dasar pendidikan Muhammadiyah di atas, khususnya nilai dasar keenam, tampak bahwa pendidikan Muhammadiyah dilakukan untuk meneguhkan Islam moderat yang menjadi salah satu ideologi bagi gerakannya. Untuk itu, kurikulum pendidikan yang dikembangkan dalam pendidikan Muhammadiyah juga mengakomodir watak Islam moderat ini. Penguatan Islam moderat ini tampak dalam penajaman ciri pendidikan Muhammadiyah yang termuat dalam kurikulum mata pelajaran al-Islam dan KeMuhammadiyahan.

Menurut Mohamad Ali, mata pelajaran al-Islam dan KeMuhammadiyahan merupakan ciri khas pendidikan Muhammadiyah, yang berbeda dengan lembaga pendidikan lainnya. Karena mata pelajaran ini menjadi ciri khas, maka ia menjadi "identitas objektif" yang diterima publik di luar Muhammadiyah. Dalam konteks ini, ada lima identitas objektif sebagai elaborasi dari al-Islam dan KeMuhammadiyahan ke dalam sistem pendidikan Muhammadiyah, yakni; 1) menumbuhkan cara berfikir tajdìd/inovatif, 2) memiliki kemampuan antisipatif, 3) mengembangkan sikap pluralistik, 4) memupuk watak mandiri, dan 5) mengambil langkah moderat. ${ }^{64}$ Jika

\footnotetext{
${ }^{63}$ Ibid., 130-131.

${ }^{64}$ Mohamad Ali, Reinvensi Pendidikan Muhammadiyah (Jakarta: Al-Wasat Publishing House, 2010), 34-35.
} 
peserta didik hasil didikan pendidikan Muhammadiyah memiliki lima identitas objektif di atas, maka menurut Mohamad Ali, nuansa perbedaan lembaga pendidikan Muhammadiyah dengan lembaga pendidikan pemerintah atau perguruan Islam lainnya akan kentara. Dalam keadaan demikian, pendidikan Muhammadiyah akan berdiri tegak tatkala berdampingan dengan lembaga pendidikan lain. ${ }^{65}$

Berdasarkan identitas objektif pendidikan Muhammadiyah di atas, memiliki sikap pluralistik dan mengambil langkah moderat merupakan bukti bahwa pendidikan Muhammadiyah menjadi penyemai Islam moderat bagi Muhammadiyah. Artinya, melalui konsep "identitas objektif pendidikan Muhammadiyah" inilah pendidikan Muhammadiyah mengandung gagasan pendidikan Islam moderat, yang disemaikan kepada peserta didiknya, sehingga mereka memiliki karakter Islam moderat, sebagaimana ideologi perjuangan Muhammdiyah itu sendiri.

\section{Gagasan Islam Moderat dalam Lembaga Pendidikan NU}

Sama dengan Muhammadiyah yang dicap sebagai organisasi Islam Indonesia dengan watak moderat, NU (Nahdlatul Ulama) yang didirikan di Surabaya pada 31 Januari $1926^{66}$ pun dikategorikan tidak jauh berbeda. Kajian Muhammad Ali, ${ }^{67}$ Masdar Hilmy, ${ }^{68}$ dan Ahmad Najib Burhani, ${ }^{69}$ jelas menyebut NU merupakan Islam moderat, bahkan merupakan bagian mainstream Islam Indonesia, sekelas dengan Muhammadiyah. Dalam konteks ini, Muqaddimah Anggaran Dasar Nahdlatul Ulama 2010 menyebutkan:

"Untuk mewujudkan hubungan antar-bangsa yang adil, damai dan manusiawi menuntut saling pengertian dan saling memerlukan, maka Nahdlatul Ulama bertekad untuk mengembangkan ukhuwwah Islâmîyah, ukhumwah Watanîyah, dan ukhumwah Insânîah yang mengemban kepentingan nasional dan internasional dengan berpegang teguh pada prinsip-prinsip al-ikhlâs (ketulusan), al-

\footnotetext{
${ }^{65}$ Ibid., 35-36.

66 Informasi mengenai pendirian NU, lihat misalnya Suharto, Filsafat Pendidikan Islam, 254-262.

${ }^{67}$ Ali, "Moderate Islam Movement", 209-214.

${ }^{68}$ Masdar Hilmy, "Whither Indonesia's Islamic Moderatism? A Reexamination on the Moderate Vision of Muhammadiyah and NU", Journal of Indonesian Islam, Vol. 07, No 01, June 2013, 24-48.

${ }^{69}$ Burhani, "Al-Tawassut wa-l I tidâl”, 564-581.
} 
'adâlah (keadilan), al-tawassut (moderasi), al-tawẫun (keseimbangan), dan al-tasâmuh (toleransi)". ${ }^{70}$

Muqaddimah Anggaran Dasar Nahdlatul Ulama 2010 di atas jelas sekali menyatakan bahwa untuk kepentingan nasional dan internasional, NU memegang prinsip-prinsip, yang salah satunya adalah prinsip moderasi (tawassut). Menurut KH. Achmad Shiddiq, prinsip tawassut merupakan karakeristik Ahl al-Sunnah wa al-Jamâ'ah, di samping prinsip raḥmah li al-álamîn. Kedua prinsip ini merupakan karakter ajaran Islam yang paling esensial. ${ }^{71}$ Di dalam menafsirkan prinsip tawassut ini, KH. Achmad Siddiq mengatakan:

"Tawassut (termasuk ittidâl dan tawâzun) bukanlah serba kompromistis dengan mencampuradukkan semua unsur (sinkretisma). Juga bukan mengucilkan diri dari menolak pertemuan dengan unsur apa-apa. Karakter tawassut bagi Islam adalah memang sejak semula Allah sudah meletakkan di dalam Islam segala kebaikan, dan segala kebaikan itu sudah pasti terdapat di antara ujung tatarruf, sifat mengujung, ekstremisma. Prinsip dan karakter tawassut yang sudah menjadi karakter Islam ini harus diterapkan dalam segala bidang, supaya Agama Islam dan sikap serta tingkah laku umat Islam selalu menjadi saksi dan pengukur kebenaran bagi semua sikap dan tingkah laku manusia umumnya". ${ }^{72}$

Dengan demikian, bagi NU, yang dimaksud moderat (tawassut) adalah lawan dari ekstrem (tatarruf), sifat mengujung ke kanan-kanan atau ke kiri-kirian. Moderat (tawassut) dimaknai oleh NU sebagai "pertengahan", yang diambil dari kata "wasata" sebagaimana disebutkan di dalam Q.S. al-Baqarah [2]: 143. ${ }^{73}$ Prinsip ini harus dipertahankan, dipelihara, dan dikembangkan sebaik-baiknya oleh kaum Ahl al-Sunnah wa al-Jamâ'ah dalam segala bidang, mencakup

\footnotetext{
70 Anggaran Dasar Nahdlatul Ulama 2010, sebagaimana dimuat dalam Pengurus Besar Nahdlatul Ulama, Keputusan Muktamar XXXII Nabdlatul Ulama (Jakarta: Sekretariat PBNU, 2011), 20.

${ }^{71}$ KH. Achmad Shiddiq, Khittah Nabdliyyah (Surabaya: Khalista-LTN NU Jawa Timur, 2006), 38. Buku ini merupakan tulisan KH. Achmad Shiddiq yang pernah dibagi-bagikan pada Muktamar NU ke-26 di Semarang tahun 1979, yang kemudian diputuskan pada Muktamar NU ke-27 di Situbondo sebagai "Khittah Nahdlatul Ulama".

72 Ibid., 62.

${ }^{73}$ Ibid., 60 .
} 
bidang akidah, sharî‘ah, akhlak, pergaulan antar-golongan, kehidupan bernegara, kebudayaan, dakwah dan bidang-bidang lainnya. ${ }^{74}$

Oleh karena prinsip moderat itu diterapkan dalam segala bidang, termasuk kehidupan bernegara, maka NU senantiasa "setia" dengan NKRI, sama dengan Muhammadiyah, menolak pendirian negara Islam. Terkait ini, Mark Woodward misalnya menilai: "Like Mubammadiyah, NU rejects the concept of an Islamic state, arguing that Islam, as a religion, places greater emphasis on piety than politics". ${ }^{75}$

Namun, pertanyaan pentingnya, apakah prinsip moderat NU itu dapat disemaikan dalam lembaga pendidikannya? Pasal 3 Anggaran Dasar Nahdlatul Ulama 2010 menyebutkan bahwa NU sebagai Badan Hukum Perkumpulan bergerak dalam bidang keagamaan, pendidikan, dan sosial. ${ }^{76}$ Untuk melaksanakan tugas-tugas kependidikan ini, NU membentuk Lembaga Pendidikan Ma'arif NU yang bertugas melaksanakan kebijakan di bidang pendidikan formal, dan mendirikan Rabithah Ma'ahid al-Islamiyah (RMI) yang bertugas melaksanakan kebijakan di bidang pondok pesantren dan pendidikan keagamaan, ${ }^{77}$ serta membentuk Lajnah Pendidikan Tinggi Nahdlatul Ulama (LPTNU) yang bertugas mengembangkan pendidikan tinggi NU. ${ }^{78}$

Data tahun 2010 menyebutkan bahwa LP Ma'arif memiliki 12.000 madrasah/sekolah tingkat dasar dan menengah, yang jumlah ini mayoritasnya tersebar di wilayah Jawa Timur. ${ }^{79}$ Apa yang dilakukan LP Ma'arif NU dengan ribuan madrasah/sekolah ini? Menurut Zamzami, Bendahara Pengurus Pusat LP Ma'arif NU, LP Ma'arif NU perlu merumuskan platform pendidikan Ma'arif, sebagai karekteristik dasar bagi pendidikan NU. Zamzami menulis:

"Di sini, LP Ma'arif NU perlu merumuskan karekteristik dasar dari pendidikan NU yang perlu diterapkan, sehingga menjadi platform pendidikan Ma'arif. Nilai-nilai Ahl al-Sunnah wa alJamâ‘ah tidak hanya diperjuangkan melalui mata pelajaran Aswaja

\footnotetext{
${ }^{74}$ Ibid., 63-68.

75 Mark Woodward, Java, Indonesia, and Islam (London: Springer Science dan Business Media B.V., 2011), 194.

76 Anggaran Dasar Nahdlatul Ulama 2010, 22.

77 Anggaran Rumah Tangga Nahdlatul Ulama 2010, sebagaimana dimuat dalam PBNU, Keputusan Muktamar, 39.

${ }^{78}$ Ibid., 41.

79 “7159 Madrasah NU Ada di Jawa Timur" dalam http://www.nu.or.id/ (diakses pada 29 Maret 2015).
} 
dan Ke-NU-an, tetapi secara kultural harus ditanamkan ke dalam seluruh aspek yang ada di lingkungan satuan pendidikan NU". ${ }^{80}$

Dengan demikian, selain mata pelajaran Aswaja dan ke-NU-an, yang menjadi karakter LP Ma'arif NU, nilai-nilai Ahl al-Sunnah wa alJamâ'ah yang merupakan ideologi $\mathrm{NU}^{81}$ perlu juga disemaikan melalui kultur pendidikan yang dibangunnya. Oleh karena itu, menurut pengakuan Masduki Baidlawi, Wakil Ketua Pengurus Pusat LP Ma'arif NU yang diwawancarai oleh Mahbib Khoiron dari NU Online, dengan jumlah 12.000 sekolah/madrasah ini NU bermaksud mengembangkan apa yang dikonsepsikan sebagai "SNP-Plus", yaitu memiliki standar nasional pendidikan (SNP) ditambah (plus) standar kearifan lokal keNU-an, yaitu mencakup mata pelajaran Ke-Aswaja-an dan nilai-nilai ke-NU-an, seperti konsep tasâmuh (toleransi), tawassut (moderat), tawẫun (seimbang), dan ittidâl (tegak). Inilah "SNP-Plus" yang menjadi kekhasan Lembaga Pendidikan Ma'arif NU, dan sekaligus menjadi Standar Mutu Maarif-nya. ${ }^{82}$ Nilai-nilai kultural inilah yang diinstalkan ke dalam LP Ma'arif NU, selain mata pelajaran Aswaja dan Ke-NU-an.

Untuk itu, model pendidikan moderat yang diusung LP Ma'arif NU adalah "SNP-Plus" yang merupakan integrasi antara mata pelajaran Aswaja dan Ke-NU-an dengan nilai-nilai kultural ke-NU-an yang berbasis ideologi Ahl al-Sunnah wa al-Jamâ'ah, yaitu tasâmub (toleransi), tawassut (moderat), tawâzun (seimbang), dan ittidâl (tegak). Pendidikan moderat SNP-Plus inilah kiranya yang menjadi instrumen NU untuk menyemaikan karakter Islam moderat kepada ribuan lembaga pendidikannya, sehingga outcome dari lembaga ini diharapkan memiliki paham Islam moderat yang menjadi karakter dan ideologi NU.

\section{Penutup}

80 Zamzami, "LP Ma'arif NU dan Satuan Pendidikan di Lingkungan NU" dalam http://www.maarif-nu.or.id/Opini/tabid/157/ID/125/LP-Maarif-NU-dan-Satuan -Pendidikan-di-Lingkungan-NU.aspx (diakses pada 29 Maret 2015).

81 Anggaran Dasar Nahdlatul Ulama 2010 Pasal 5 menegaskan bahwa:

"Nahdlatul Ulama beraqidah Islam menurut faham Ahl al-Sunnah wa al-Jamâ'ah dalam bidang aqidah mengikuti mazhab Imam Abû Hạan al-Ash'arî dan Imam Abû Manșûr al-Mâturidî; dalam bidang fiqh mengikuti salah satu dari mazhab empat (Ḥanafî, Mâlikî, Shâfîî, dan Hạbalî); dan dalam bidang tasawuf mengikuti mazhab Imam al-Junayd al-Baghdâdî dan Abû Hâmid al-Ghazâlî”.

82 "Maarif NU, Jembatan Sekolah dengan Pemerintah" dalam dalam http:/ /www.nu.or.id/ (diakses pada 29 Maret 2015). 
Muhammadiyah dan NU merupakan dua organisasi Islam terbesar di Indonesia yang karenanya sering dianggap sebagai mainstream Islam Indonesia. Kedua ormas Islam ini, meskipun memiliki ideologi keislaman yang berbeda, tapi keduanya memiliki watak dan karakter yang sama, yaitu berjuang untuk mewujudkan Islam moderat di Indonesia melalui jalur pendidikan, sehingga perjuangan keduanya untuk mengukuhkan Islam moderat, lebih ditekankan pada tataran teologis-kultural daripada politis.

Muhammadiyah memiliki sejumlah lembaga pendidikan dengan ciri khas utamanya adalah adanya mata pelajaran al-Islam dan KeMuhammadiyah-an. Dengan konsep "identitas objektif pendidikan Muhammadiyah", mata pelajaran ini dirancang untuk menjadi instrumen bagi Muhammadiyah dalam rangka menyemaikan karakter Islam moderat bagi peserta didiknya. Sementara NU mempunyai Lembaga Pendidikan Ma'arif NU dengan ciri khas adanya mata pelajaran Aswaja dan Ke-NU-an. Melalui konsep "SNP-Plus", Lembaga Pendidikan Ma'arif NU merupakan wahana NU untuk menyemaikan karakter Islam moderat bagi para peserta didiknya.

Dengan demikian, melalui kajian ulang ini, terbukti bahwa Muhammadiyah dan NU memiliki gagasan untuk mencanangkan pendidikan Islam moderat melalui perjuangan teologis-kulturalnya masing-masing. Akan tetapi, pertanyaan penting yang perlu diajukan, apakah kedua organisasi ini mampu untuk terus berjuang mengusung Islam moderat melalui gagasan pendidikan Islam moderatnya? Mengingat Islam Indonesia dewasa ini sudah memiliki banyak varian ideologi radikal, yang tentunya varian ideologi radikal ini juga mempunyai lembaga pendidikan sebagai wahana untuk menyemaikan ideologi radikalnya. Oleh karena itu, Islam Indonesia saat ini sedang mengalami semacam pertarungan ideologis antara Islam moderat versus Islam radikal. Tragisnya, pertarungan ideologis ini terjadi dalam kancah lembaga pendidikan Islam. Bagaimana pertarungan ini terjadi, tentunya berada di luar jangkauan kajian ini.

\section{Daftar Rujukan}

'Abûd, 'Abd al-Ghanî. Fî al-Tarbîyah al-Islâmîyah. t.tp.: Dâr al-Fikr al'Arabî, 1977.

Ali, Mohamad. Reinvensi Pendidikan Muhammadiyah. Jakarta: Al-Wasat Publishing House, 2010.

Ali, Muhammad. "Moderate Islam Movement in Contemporary Indonesia" dalam Rizal Sukma dan Clara Joewono (eds.), Islamic 
Thoughts and Movements in Contemporary Indonesia. Jakarta: Center for Strategic and International Studies, 2007.

-----. Teologi Pluralis-Multikultural: Menghargai Kemajemukan, Menjalin Kebersamaan. Jakarta: Penerbit Buku Kompas, 2003.

Arifin, Syamsul. "Membendung Arus Radikalisasi di Indonesia", Islamica, Vol. 8, Nomor 2, 2014.

Arnold, Thomas W. Sejarah Dakwah Islam, terj. A. Nawawi Rambe. Jakarta: Widjaya, 1985.

Azra, Azyumardi. "Bali and Southeast Asian Islam: Debunking the Myths" dalam Kumar Ramakrishna dan See Seng Tan (eds.), After Bali: The Threat of Terrorism in Southeast Asia. Singapore: World Scientific Publishing Co. Pte. Ltd, 2003.

-----. "Distinguishing Indonesian Islam: Some Lessons to Learn" dalam Jajat Burhanudin dan Kees van Dijk (eds.), Islam in Indonesia: Contrasting Images and Interpretations. Amsterdam: Amsterdam University Press, 2013.

Badruttaman, Nurul. "Dakwah Islam di Tengah Tantangan Globalisasi: Pemikiran dan Kontribusi Tarmizi Taher" dalam Hery Sucipto (ed.). Islam Madzhab Tengab: Persembahan 70 Tabun Tarmizi Taher. Jakarta: Grafindo Khazanah Ilmu, 2007.

Bakker Anton., dan Zubair, Achmad Charris. Metodologi Penelitian Filsafat. Yogyakarta: Kanisius, 1998.

Burhani, Ahmad Najib. "Al-Tawassut wa-l I'tidâl: the NU and Moderatism in Indonesian Islam", Asian Journal of Social Science, Vol. 40, Issue 5-6, 2012.

-----. "Pluralism, Liberalism and Islamism: Religious Outlook of the Muhammadiyah Islamic Movement in Indonesia". Tesis--Fakulty of Humanities, University of Manchester, 2007.

Burhanudin, Jajat., dan Dijk, Kees van (eds.). Islam in Indonesia: Contrasting Images and Interpretations. Amsterdam: Amsterdam University Press, 2013.

Fanani, Ahmad Fuad. "Akar Radikalisme dan Terorisme", Suara Merdeka, Jum'at, 07 Oktober 2005.

Fealy, Greg., dan Hooker, Virginia (eds.). Voices of Islam in Southeast Asia: A Contemporary Sourcebook. Singapore: ISEAS, 2006.

Gutek, Gerald L. Philosophical and Ideological Perspectives on Education. New Jersey: Prentice Hall, 1988. 
Hanafi, Muchlis M. Moderasi Islam: Menangkal Radikalisasi Berbasis Agama. Jakarta: Ikatan Alumni al-Azhar dan Pusat Studi al-Qur'ân, 2013.

Hasan, Noorhaidi. Islam Politik di Dunia Kontemporer: Konsep, Genealogi, dan Teori. Yogyakarta: Suka-Press, 2012.

Hilmy, Masdar. "The Politics of Retaliation: the Backlash of Radical Islamists to Deradicalization Project in Indonesia", Al-Jâmi 'ab: Journal of Islamic Studies, Vol. 51, No. 1, 2013.

----. "Whither Indonesia's Islamic Moderatism? A Reexamination on the Moderate Vision of Muhammadiyah and NU", Journal of Indonesian Islam, Vol. 07, Number 01, June 2013.

----. "Whither Indonesia's Islamic Moderatism? A Reexamination on the Moderate Vision of Muhammadiyah and NU", Journal of Indonesian Islam, Vol. 07, No 01, June 2013.

Huda, Nor. Islam Nusantara: Sejarah Sosial Intelektual Islam di Indonesia. Yogyakarta: Ar-Ruzz Media, 2007.

Mardiatmadja. "Peran Perguruan Swasta: Khususnya Perguruan Katolik dalam Pendidikan Nasional", dalam http://www.mardiatmadja.org /Tulisan Lepas Perguruan Swasta. htm, diakses 20 Februari 2010.

Mufid, Ahmad Syafi'i (ed.). Perkembangan Pabam Keagamaan Transnasional di Indonesia. Jakarta: Puslitbang Kehidupan Keagamaan, Badan Litbang dan Diklat Kementerian Agama, 2011.

Nashir, Haedar. Memahami Ideologi Muhammadiyah. Yogyakarta: Suara Muhammadiyah, 2015.

Nurjannah. Radikal us Moderat: Atas Nama Dakwah, Amar Makruf Nabi Mungkar dan Jihad Perspektif Psikologi. Yogyakarta: Aswaja Presindo, 2013.

Pengurus Besar Nahdlatul Ulama, Keputusan Muktamar XXXII Nabdlatul Ulama. Jakarta: Sekretariat PBNU, 2011.

Pratte, Richard. Ideology and Education. New York: David McKay Company, 1977.

PUSHAM UII, Tim. Bersama Bergerak: Riset Aktivis Islam di Dua Kota. PUSHAM UII: Yogyakarta, Oktober 2009.

Rokhmad, Abu. "Radikalisme Islam dan Upaya Deradikalisasi Paham Radikal", Walisongo: Jurnal Penelitian Sosial Keagamaan, Volume 20, Nomor 1, 2012. 
Rubaidi, A. Radikalisme Islam: Nabdlatul Ulama dan Masa Depan Moderatisme Islam di Indonesia. Surabaya: PWNU Jawa Timur, 2010. Sabirin, Rahimi. Islam dan Radikalisme. Yogyakarta: Ar-Rasyid, 2004.

Sastrapratedja, M. "Pancasila sebagai Ideologi dalam Kehidupan Budaya", dalam Oetojo Oesman dan Alfian (eds.), Pancasaila sebagai Ideologi dalam Berbagai Bidang Kehidupan Bermasyarakat, Berbangsa, dan Bernegara. Jakarta: BP-7 Pusat, 1991.

Shihab, Alwi. "The Muhammadiyah Movement and Its Controversy with Christian Mission in Indonesia". Disertasi--Temple University, 1995.

Sucipto, Hery. "Tarmizi Taher dan Islam Madzhab Tengah", pengantar editor dalam Hery Sucipto (ed.). Islam Madð̧ab Tengah: Persembahan 70 Tabun Tarmizi Taber. Jakarta: Grafindo Khazanah Ilmu, 2007.

Suharto, Toto. Filsafat Pendidikan Islam: Menguatkan Epistemologi Islam dalam Pendidikan. Yogyakarta: Ar-Ruzz Media, 2014.

Tafsir. "Simpang Jalan-Simpang Jalan Muhammadiyah", Maarif, Vol. 4, No. 2, 2009.

Tanfidz. Keputusan Muktamar Satu Abad Mubammadiyab: Muktamar Muhammadiyah Ke-45. Yogyakarta: Pusat Pimpinan Muhammadiyah, 2010.

Tilaar, H.A.R. Pendidikan dan Kekuasaan: Suatu Tinjauan dari Perspektif Studi Kultural. Magelang: Indonesia Tera, 2003), 120.

Turmudi, Endang., dan Sihbudi, Riza. Islam dan Radikalisme di Indonesia. Jakarta: LIPI Press, 2005.

Umar, Ahmad Rizky Mardhatillah. "Melacak Akar Radikalisme Islam di Indonesia", Jurnal Ilmu Sosial dan Ilmu Politik, Vol. 14, Nomor 2, 2010.

Wahid, Abdurrahman. Islamku, Islam Anda, Islam Kita: Agama Masyarakat Negara Demokrasi. Jakarta: The Wahid Institute, 2006.

Woodward, Mark. Java, Indonesia, and Islam. London: Springer Science dan Business Media B.V., 2011.

Zamzami. "LP Ma'arif NU dan Satuan Pendidikan di Lingkungan NU” dalam http://www.maarif-nu.or.id/Opini/tabid/157 /ID/125/LP-Maarif-NU-dan-Satuan-Pendidikan-di-LingkunganNU.aspx/diakses pada 29 Maret 2015. 


\section{Internet}

Koran Sindo versi online, "Kemenag Dorong UIN Jadi Kampus Riset" dalam http://m.koran-sindo.com/node/325385, (diakses pada 1 Juni 2014).

"7159 Madrasah NU Ada di Jawa Timur" dalam http://www.nu.or.id/ (diakses pada 29 Maret 2015).

"Indonesia Diharapkan Jadi Barometer Islam Moderat" dalam http://www.nu.or.id/ (diakses pada 29 Maret 2015).

"Jokowi Ingin Bangun Universitas Islam Moderat" dalam http://www.pikiran-rakyat.com/pendidikan/2015/06/05/329989 /jokowi-ingin-bangun-universitas-islam-moderat (diakses pada 13 Juni 2015) dan "Jokowi Ingin Pertahankan Pendidikan Islam Moderat" dalam http://nasional.news.viva.co.id/news / read /634595-jokowi-ingin-pertahankan-pendidikan-islam-moderat (diakses pada 13 Juni 2015).

"Maarif NU, Jembatan Sekolah dengan Pemerintah" dalam dalam http://www.nu.or.id/ (diakses pada 29 Maret 2015). 